of entry of bilirubin- ' $\mathrm{C}$ into the central nervous system. J. Clin. Invest., 45: 678 (1966).

10. Fog, J., and Bakken, A. F.: Absorptivity of alkaline bilirubin and bilirubin in serum. Scand. J. Clin. Lab. Invest., 20: 70 (1967).

11. Gartner, L. M., and Lee, K. S.: Bilirubin transport, free fatty acids and a new concept for the pathogenesis of kernicterus. Presented at the International Symposium on Bilirubin Metabolism in the Newborn, Jerusalem, Israel. April 1974. (In press.)

12. Greenfield, S. S., and Majumdar, A. P. N.: Bilirubin encephalopathy: Effect on protein synthesis in the brain of the Gunn rat. J. Neurol. Sci., 22: 83 (1974).

13. Herz, H., and Dybkaer, R.: Molar absorption coefficients for bilirubin in adult and infant serum with determination of an isosbestic point. Scand. J. Clin. Lab. Invest., 29: 217 (1972).

14. Jackson. S. H., and Hernandez. A. H.: A new "bilirubinometer" and its use in estimating total and conjugated bilirubin in serum. Clin. Chem., 16:462 (1970).

15. Jacobsen, J., and Fedders, O.: Determination of non-albumin-bound-bilirubin in human serum. Scand. J. Clin. Lab. Invest., 26: 237 (1970).

16. Jendrassik, L., and Grof, P.: Vereinfachte photometrische Methoden zur Bestimmung des Blut-Bilirubins. Biochem. Z., 297: 81 (1939).

17. Kapoor, C. L., Kishna Murti, C. R., and Bajpai, P. C.: Toxic effect of bilirubin on human red blood cell and its reversal with lipids. Indian J. Med. Res., 60: $918(1972)$.

18. Lowry, O, H., Rosebrough, N. J., Farr, A. L, and Randall, R. J: Protein measurement with the Folin phenol reagent. J. Biol. Chem., 193: 265 (1951).

19. Martin, N. H.: Preparation and properties of serum and plasma proteins. XXI Interactions with bilirubin. 1. Amer. Chem. Soc. 71: 1230 (1967)

20. McDonagh, A. F.: The role of singlet oxygen in bilirubin photooxidation. Biochem. Biophys. Res. Commun., 44: 1306 (1971).

21. Michaelsson, M.: Evaluation of method for determination of bilirubin in serum using direct spectrophotometry. Scand. J Clin. Lab. Invest. 30:387 (1972).

22. Mustafa, M. G., Cowger, M. L., and King, T. E.: The effect of bilirubin on mitochondrial reactions. J. Biol. Chem., 244: 6403 (1969).

23. Mustafa, M. G., and King, T. E.: Binding of bilirubin with lipids: A possible mechanism of its toxic reactions in mitochondria. J. Biol. Chem., 245: 1084 (1970).

24. Odell, G. B.: Studies in kernicterus. I. The protein binding of bilirubin. J. Clin. Invest., $3 \dot{8}: 823$ (1959)

25. Odell, G. B., Bolen, J. L., Poland, R. L., Seungdamrong, S., and Cukier, J. O. Protection from bilirubin nephropathy in jaundiced Gunn rats. Gastroenterology, 66: 1218 (1974)

26. Odell, G. B., Cohen, S. N., and Kelly, P. C.: Studies in kernicterus. II. The determination of the saturation of serum albumin with bilirubin. J. Pediat., 74 : 214 (1969).

27. Ostrow, J. D., and Branham, R. V.: Photodecomposition of bilirubin and

Copyright (C) 1976 International Pediatric Research Foundation, Inc. biliverdin in vitro. Gastroenterology, 58: $15(1970)$

28. Ostrow, J. Hammaker, L and Schmid. R. The preparation of crystalline bilirubin-C". J. Clin. Invest., 40:1442 (1962)

29. Overbeek, J. T. G., Vink, C. L. J., and Denstra, H.: The solubility of bilirubin. Rec. Trav. Chim. Pays-Bas, 74(4): 81 (1955).

30. Petrich, V., Gempp-Friedrich, W and Gobel, U. Comparative measurements of enzyme activities and 2,3-diphosphoglycerate in the erythrocytes of newborns with and without transitory hyperbilirubinemia. Acta Pediat. Stockh., 62: 596 (1973).

31. Rose, A. L., and Johnson, A. B.: Bilirubin encephalopathy: Neuropathological and histochemical studies in the Gunn rat model. Neurology, 22: 420 (1972).

32. Sioni, R., Sauwalder, H., and Richterich, R.: Ein vergleich physikalischer und chemischer Methoden zur Bestimmung des Plasmabilirubins. Schweiz. Med. Wschr. 99: 1784 (1969).

33. Shinowara, G. Y.: Spectrophotometric studies in blood serum and plasma. The physical determination of hemoglobin and bilirubin. Amer. J. Clin. Pathol., 24: 696 (1954).

34. Schiff, D. Chan, G. and Stern, L. Sephadex G-25 quantitative estimation of free bilirubin potential in jaundiced newborn infants` sera: A guide to the prevention of kernicterus. J. Lab. Clin. Med., 80: 445 (1972).

35. Standards Committee: A uniform bilirubin standard. Recommendations of the College of American Pathologists. Amer. J. Clin. Pathol.. 39: 90 (1963).

36. Vold, M. J., and Vold, R. D.: Colloid Chemistry, p. 9 (Van Nostrand Reinhold Co., New York, 1964)

37. Wennberg, R. P., and Cowger, M. L.: Spectral characteristics of bilirubin bovine albumin complexes. Clin. Chim. Acta, 43: 55 (1973).

38. With, T. K.: Spectral absorption of bilirubin. Measurements in pure aqueous solution and in solutions containing human sera. Acta Physiol. Scand., 10: 172 (1945).

39. Woolley, P. V., III, and Hunter, M. J. Binding and circular dichroism data on bilirubin-albumin in the presence of oleate and salicylate. Arch. Biochem. Biophys., 140: 197 (1970).

40. Zamet, P., and Chunga, F.: Separation by gel filtration and microdetermination of unbound bilirubin. II Study of sera in icteric newborn infants. Acta Pediat. Scand. 60: 33 (1971).

41. Dr. Gartner is a Career Development Awardee from the National Institute for Child Health and Human Development.

42. This work has been supported by grants from the National Institute for Child Health and Human Development NIH 5 R01-HD 03783 and the Gail I. Zuckerman Foundation for Research in Chronic Liver Diseases in Children.

43. Requests for reprints should be addressed to: L. M. Gartner, M.D., Department of Pediatrics, Albert Einstein College of Medicine, 1300 Morris Park Ave., Bronx, N.Y. 10461 (USA).

44. Accepted for publication March 15, 1976

Pediat. Res. 10: 788-791 (1976)

Bilirubin

hyperbilirubinemia $\mathrm{Rh}$ erythroblastosis liver

\title{
The Effect of Promethazine Hydrochloride on Bilirubin Metabolism in the Rat
}

\author{
SERGIO L. VAISMAN, KWANG-SUN LEE, AND LAWRENCE M. GARTNER ${ }^{(22)}$ \\ Division of Neonatology, Department of Pediatrics, The Rose F. Kenned. Center for Research in Mental Retardation \\ and Human Development and the Liver Research Center, Albert Einstein College of Medicine, \\ Bronx, New York, USA
}

\section{Extract}

The effect of 21 days of promethazine-HCl administration on hepatic bilirubin metabolism and transport was studied in adult rats. A significant increase in mean cumulative hepatic bilirubin uptake $(84.5 \pm 7.6(\mathrm{SE}) \mu \mathrm{g} / 100 \mathrm{~g} / \mathrm{min}$ in controls $v s$. $110.0 \pm 4.3 \mathrm{in}$ treated rats), mean hepatic glucuronide conjugation $(1,330 \pm 86$ (SE) $\mu \mathrm{g}$ bilirubin conjugated $/ \mathrm{g}$ liver $/ \mathbf{4 0} \mathrm{min}$ in controls $v s$. $1,713 \pm 61$ in treated rats), and mean maximal hepatic excretion $(47.2 \pm 4.9(\mathrm{SE}) \mu \mathrm{g} / 100 \mathrm{~g} / \mathrm{min} v s .63 .5 \pm 2.7)$ was observed in treated animals. Mean total liver weight and total hepatic protein also increased significantly.

These observations suggest that promethazine is an inducer of protein and enzyme synthesis in rat liver and is capable of significantly stimulating the three major steps in hepatic disposal of bilirubin.

\section{Speculation}

The stimulatory effect of promethazine on bilirubin metabolism and transport introduces a second or alternate explanation for the 
reported effectiveness of the drug in ameliorating hyperbilirubinemia in human $\mathbf{R}$ h erythroblastosis. Thus, the drug may either decrease bilirubin synthesis through inhibition of macrophage destruction of sensitized erythrocytes or by other immunosuppressive action, or it may enhance hepatic bilirubin disposal mechanisms. If the major effect of promethazine is stimulation of bilirubin metabolism and transport in the fetus, then one may question whether it has any advantage over other stimulatory agents, such as phenobarbital.

Experience with prolonged high dose administration of promethazine $-\mathrm{HCl}$ (Phenergan- $\mathrm{HCl}$ ) to pregnant women has suggested that it may ameliorate some of the effects of erythroblastosis fetalis in Rh-incompatible sensitized gestations $(2,8)$. Its beneficial effects in possibly reducing the severity of hyperbilirubinemia and anemia have been attributed entirely to the ability of the drug to suppress macrophage activity in the fetal reticuloendothelial system, thereby reducing the rate of fetal erythrocyte lysis (8).

Promethazine is a potent inhibitor of several immune mechanisms, as had been reported previously by others (7) and as we have observed in studies from our own institution in infants whose mothers had been so treated $(16,17)$. Nevertheless, the clinical course of several of these neonates with $\mathrm{Rh}$ erythroblastosis whose mothers had been treated with promethazine at $75-175 \mathrm{mg} /$ day for $2-14$ weeks suggested that supression of hemolysis would not alone account for the observed effect of therapy in preventing the expected rise in serum bilirubin concentrations (16). The continuation of severe hemolysis without a comparable increase in serum bilirubin concentration suggested the possibility that promethazine- $\mathrm{HCl}$ enhanced bilirubin disposal mechanisms of the liver in a manner similar to that of phenobarbital, benzpyrene, dichlordiphenyltrichlormethylmethane, and other microsomal enzymeinducing agents $(3,5)$.

As an initial approach to this question, hepatic bilirubin uptake, conjugation, and excretion were studied in adult rats which had been treated with promethazine- $\mathrm{HCl}$.

\section{MATERIALS AND METHODS}

Sprague-Dawley female adults rats weighing 235-260 g were obtained from Marland Breeding Farms, Wayne, N. J. The animals were maintained in a stable environment and fed Purina rat chow. Pure promethazine- $\mathrm{HCl}$ (a gift of Wyeth Laboratories Inc.) was prepared in normal saline $(250 \mathrm{mg} / 100 \mathrm{ml})$ and administered in doses of $25 \mathrm{mg} / \mathrm{kg} / 24 \mathrm{hr} \mathrm{sc}$ once a day for 21 days. Control animals received the same volume of normal saline. Animals were weighed weekly. In one group of animals (eight treated, six control) hepatic bilirubin UDP-glucoronyl transferase activity was measured according to a method previously described (6).

The remaining animals underwent cannulation of the trachea, external jugular vein, and common bile duct with pentobarbital anesthesia. Body temperature was maintained with the use of a thermostatically controlled heating cabinet and an infrared lamp; rectal temperatures were measured to insure maintenance of temperature between 99.0 and $100.0^{\circ} \mathrm{F}$. Hepatic uptake and excretion of bilirubin were studied and calculated as previously described (6), with two 30-min periods of infusion of normal saline followed by six 15 -min periods of infusion of bilirubin $(100 \mathrm{mg} / 100$ $\mathrm{ml}$ buffered saline, $\mathrm{pH}$ 7.8). Bile was collected on ice in the dark during each study period. Blood was collected terminally. Livers were removed, blotted, and weighed immediately after the rats were killed at the termination of the last period. Total liver protein was measured according to the method of Lowry (10).

Results are expressed as the mean value $\pm 1 \mathrm{SE}$. The two tailed $t$-test was used for determination of statistically significant differences between groups at a significance level of $P<0.05$ (18).

\section{RESULTS}

The results are summarized in Table 1.

\section{ENDOGENOUS BILIRUBIN EXCRETION}

Bile flow and bile bilirubin concentrations during the 60 -min period of saline infusion, before bilirubin infusion, is designated endogenous bile flow and endogenous bile bilirubin concentration, respectively. The product of these two parameters yields the endogenous bilirubin excretion which, in the steady state of these animals, represents the load of bilirubin presented to liver and, therefore, a measure of bilirubin synthesis. Mean endogenous bilirubin excretion in the control rats was $0.361 \pm 0.03 \mu \mathrm{g} / 100 \mathrm{~g}$ body $\mathrm{w} / \mathrm{min}$ while it was more than double $(0.782 \pm 0.12)$ in the treated animals. This difference is significant $(P<0.01)$.

\section{CUMULATIVE HEPATIC UPTAKE}

Cumulative hepatic bilirubin uptake is a measure of the maximal net rate of movement of unconjugated bilirubin from

Table 1. Effects of Promethazine-HCl on bilirubin metabolism in rat ${ }^{\mathrm{i}}$

\begin{tabular}{|c|c|c|c|c|c|}
\hline & $n$ & Control & $n$ & Promethazine- $\mathrm{HCl}$ & $P$ \\
\hline Cumulative hepatic uptake $(\mu \mathrm{g} / 100 \mathrm{~g} / \mathrm{min})$ & 8 & $84.5 \pm 7.6$ & 10 & $110.0 \pm 4.3$ & $<0.01$ \\
\hline Glucuronyl transferase ( $\mu \mathrm{g}$ bilirubin conjugated/g liver/40 min) & 6 & $1330 \pm 86$ & 8 & $1713 \pm 61$ & $<0.01$ \\
\hline Endogenous bilirubin $(\mu \mathrm{g} / 100 \mathrm{~g} / \mathrm{min})$ & 8 & $0.361 \pm 0.03$ & 10 & $0.782 \pm 0.12$ & $<0.01$ \\
\hline Bile bilirubin $(\mathrm{ng} / 100 \mathrm{ml})$ & 8 & $604.5 \pm 62$ & 10 & $668.7 \pm 36$ & $>0.20$ \\
\hline Bile flow $(\mu 1 / 100 \mathrm{~g} / \mathrm{min})$ & 8 & $7.8 \pm 0.89$ & 10 & $9.5 \pm 0.63$ & $>0.10$ \\
\hline Hepatic bilirubin excretion $(\mu \mathrm{g} / 100 \mathrm{~g} / \mathrm{min})$ & 8 & $47.2 \pm 4.9$ & 10 & $63.5 \pm 2.7$ & $<0.02$ \\
\hline Total bilirubin excreted $(\mathrm{mg})$ & 8 & $19.6 \pm 2.1$ & 10 & $24.8 \pm 1.4$ & $<0.05$ \\
\hline $\begin{array}{l}\text { Serum bilirubin } \\
\quad \text { Indirect }(\mathrm{mg} / 100 \mathrm{ml})\end{array}$ & 8 & $15.6 \pm 2.6$ & 10 & $13.1 \pm 1.6$ & $>0.20$ \\
\hline Direct $(\mathrm{mg} / 100 \mathrm{ml})$ & 8 & $1.6 \pm 0.7$ & 10 & $2.0 \pm 1.0$ & $>0.20$ \\
\hline $\begin{array}{l}\text { Liver bilirubin } \\
\text { Indirect }(\mathrm{mg} / 100 \mathrm{ml})\end{array}$ & 8 & $17.1 \pm 2.3$ & 10 & $15.2 \pm 2.3$ & $>0.20$ \\
\hline Direct $(\mathrm{mg} / 100 \mathrm{ml})$ & 8 & $7.7 \pm 1.0$ & 10 & $9.4 \pm 2.4$ & $>0.20$ \\
\hline Liver protein concentration (mg/g liver) & 6 & $189 \pm 5.5$ & 8 & $192 \pm 6.1$ & $>0.20$ \\
\hline Total liver protein $(\mathrm{mg} / 100 \mathrm{~g}$ body wt) & 6 & $663.4 \pm 66$ & 8 & $760.8 \pm 80$ & $<0.05$ \\
\hline Liver weight $(\mathrm{g} / 100 \mathrm{~g}$ body $\mathrm{wt})$ & 14 & $3.46 \pm 0.04$ & 18 & $3.83 \pm 0.07$ & $<0.001$ \\
\hline Body weight at start of injections (g) & 14 & $246.7 \pm 10.1$ & 18 & $247.9 \pm 10.4$ & $>0.20$ \\
\hline Body weight at end of 21 days of injections ( $g$ ) & 14 & $286.6 \pm 14.6$ & 18 & $277.7 \pm 16.9$ & $>0.10$ \\
\hline
\end{tabular}

\footnotetext{
:All values represent the mean $\pm 1 \mathrm{SE}$.
} 
plasma into the liver and was calculated as previously described (6). Cumulative hepatic uptake of bilirubin was $84.5 \pm 7.6 \mu \mathrm{g} / 100$ $\mathrm{g} / \mathrm{min}$ in control rats. The promethazine-HCl-treated group had a significant increase to $110.0 \pm 4.3(P<0.01)$.

\section{BILIRUBIN UDP-GLUCURONYL TRANSFERASE ACTIVITY}

The control group had a mean enzyme activity estimated in vitro of $1,330 \pm 86 \mu \mathrm{g}$ bilirubin conjugated $/ \mathrm{g}$ liver $/ 40 \mathrm{~min}$ whereas the promethazine-HCl-treated group had a significant increase to $1,713 \pm 61(P<0.01)$.

\section{MAXIMAL BILE BILIRUBIN CONCENTRATION}

Maximal bile bilirubin concentration was calculated for each animal as the mean of the three periods identified as having maximal hepatic bilirubin excretion. The mean maximal bilirubin concentration achieved in bile was not significantly different between control and promethazine- $\mathrm{HCl}$ groups: $604.5 \pm 62$ and $668.7 \pm 36 \mathrm{mg} / 100 \mathrm{ml}$, respectively $(P>0.20)$.

\section{BILE FLOW}

Bile flow as calculated for each animal was a mean of the same three periods used for mean maximal hepatic bilirubin excretion. The control group had a mean bile flow of $7.8 \pm 0.89 \mu \mathrm{g} / 100 \mathrm{~g}$ body $\mathrm{wt} / \mathrm{min}$ and the promethazine- $\mathrm{HCl}$ group, $9.5 \pm 0.63$. This difference is not significant $(P>0.10)$.

\section{MAXIMAL HEPATIC BILIRUBIN EXCRETION}

Maximal hepatic excretion of bilirubin was calculated for each animal as a mean of the three highest values of the six bilirubin infusion periods. This represents the maximal rate at which the liver can transfer conjugated bilirubin out of the liver. The mean maximal hepatic bilirubin excretion of $63.5 \pm 2.7 \mu \mathrm{g} / 100 \mathrm{~g} / \mathrm{min}$ in the promethazine- $\mathrm{HCl}$ group was significantly greater than the $47.2 \pm 4.9$ of the control group $(P<0.02)$.

\section{TOTAL BILIRUBIN EXCRETED}

The control group excreted $19.6 \pm 2.1 \mathrm{mg}$ bilirubin during the 90 -min bilirubin infusion period whereas the promethazine- $\mathrm{HCl}$ group excreted a significantly greater amount, $24.8 \pm 1.4 \mathrm{mg}(P<$ $0.05)$.

\section{SERUM AND LIVER BILIRUBIN CONCENTRATIONS}

At the completion of each infusion study, bilirubin concentrations were determined in liver and serum. Control rats had a mean indirect-reacting bilirubin concentration in serum of $15.6 \pm 2.6$ $\mathrm{mg} / 100 \mathrm{ml}$ and a mean direct-reacting bilirubin in serum of $1.6 \pm$ 0.7. Promethazine-HCl-treated rats had $13.1 \pm 1.6$ and $2.0 \pm 1.0$, respectively. The differences were not significant for either direct or indirect-reacting bilirubin concentrations $(P>0.20)$.

The mean concentration of indirect-reacting bilirubin in liver at the completion of the study in control animals was $17.1 \pm 2.3$ $\mathrm{mg} / 100 \mathrm{ml}$ and the mean direct-reacting bilirubin was $7.7 \pm 1.0$. Promethazine-HCl-treated rats had $15.2 \pm 2.3$ and $9.4 \pm 2.4$, respectively. The differences between control and treated animals are not significant $(P>0.20)$.

\section{TOTAL BODY WEIGHT BEFORE AND AFTER TREATMENT}

The mean total body weight at start of treatment was similar in both groups: $246.7 \pm 10.1 \mathrm{~g}$ for the control group and $247.9 \pm 10.4$ for the promethazine-HCl-treated rats. After the 21-day treatment the total body weight was higher in the control group $(286.6 \pm$ 14.6) g compared with promethazine-HCl-treated rats $(277.7 \pm$ $16.9)$ but the difference is not significant $(P>0.10)$.

\section{LIVER WEIGHT}

The mean liver weight for the control group was $3.46 \pm 0.04$ $\mathrm{g} / 100 \mathrm{~g}$ body wt. The promethazine-HCl-treated rats had a significantly greater liver weight of $3.83 \pm 0.07(P<0.001)$.

\section{LIVER PROTEIN CONCENTRATION}

Liver protein concentration in whole liver homogenates in the control group was $189 \pm 5.5 \mathrm{mg} / \mathrm{g}$ liver. After 3 weeks of promethazine- $\mathrm{HCl}$ administration the treated group demonstrated a small but nonsignificant increase to $192 \pm 6.1(P>0.20)$. Total liver protein was $663.4 \pm 66 \mathrm{mg} / 100 \mathrm{~g}$ body wt in the control group and $760.8 \pm 80$ in the treated group. This increase is significant $(P<0.05)$.

\section{DISCUSSION}

Three weeks of promethazine- $\mathrm{HCl}$ adminisration produced a significant enhancement of both bilirubin metabolism and transport in the rat. These effects of promethazine- $\mathrm{HCl}$ are similar to those described for phenobarbital which has been shown to increase bilirubin conjugation $(3,5)$ excretion $(1,15)$, and possibly uptake $(9,13,14)$. Promethazine- $\mathrm{HCl}$ also increased liver weight and total liver protein as has been observed previously following prolonged administration of most enzyme inducers. Furthermore, the significantly higher endogenous bilirubin excretion in the promethazine-HCl-treated rats strongly suggests that bilirubin production is also increased in these animals, an observation not previously noted with phenobarbital.

The increase in hepatic transport and conjugation of bilirubin strongly suggests that promethazine is a potent stimulator or inducer of enzyme and protein synthesis, as has been noted for a number of other drugs of the antihistamine group (4). This observation increases the likelihood that a significant portion of the clinical effectiveness of promethazine resides in its ability to enhance bilirubin disposal. The suggested increase in bilirubin production noted in the promethazine-treated rats, although significant, is of relatively small degree compared with enhancement of other transport parameters and is heavily compensated for by increased excretion.

The precise mechanism by which any of these drugs increase hepatic uptake and excretion is unknown. It has been suggested that uptake is enhanced by increased synthesis of the cytoplasmic bilirubin binding protein, ligandin ("Y"), and that excretion is enhanced by increased bile salt-independent bile flow, and/or by increased bile salt synthesis and pool size $(9,12-14)$.

In some of the treated human infants the effect on bilirubin disposal mechanisms appeared to be greater than the role of the drug in reducing hemolysis. The question is raised, therefore, of whether promethazine has any advantage over phenobarbital, which has already been shown to reduce the number of exchange transfusions required in newborns with rhesus hemolytic disease (11). If the long term immunosupressive effects produced by promethazine- $\mathrm{HCl}$ prove to have serious consequences later in life, as has been suggested by some of the early studies from this department, then the clinical usefulness of promethazine would be in much doubt (16). Although the number of women sensitized to $\mathrm{Rh}$ antigen has been reduced markedly in recent years, comparative study of the effects of promethazine and phenobarbital in potential $\mathrm{Rh}$ erythroblastosis during pregnancy, neonatal, and infancy periods would clarify some of these issues.

\section{SUMMARY}

A significant increase in hepatic bilirubin uptake, hepatic conjugation, and maximal hepatic excretion was observed in adult rats after promethazine administration for 21 days. Total liver weight and hepatic protein were also increased significantly by the treatment. 
The study suggests that promethazine is a potent stimulator or inducer of enzyme and protein synthesis and the benefit of promethazine in the treatment of $\mathrm{Rh}$ erythroblastosis may relate to enhancement of bilirubin disposal mechanisms.

\section{REFERENCES AND NOTES}

1. Berthelot, P., Erlinger, S., and Dhumeaux, D.: Phenobarbital enhancement of bile flow. Gastroenterology, 60: 614 (1971).

2. Bierme-Alie-Enjalbert, S.: Les formes graves "in utero" de la maladie hemolitique perinatale par incompatibilite rhesus (Centre Regional de Transfusion Sanguine et d'Hematologie, Toulouse, 1967).

3. Catz, C., and Yaffe, S.: Barbiturate enhancement of bilirubin conjugation and excretion in young and adult animals. Pediat. Res., 2: 361 (1968).

4. Conney, A. H.: Pharmacological implications of microsomal enzyme induction. Pharmacol. Rev., 19: 317 (1967).

5. DeLeon, A., Gartner, L. M., and Arias, I. M.: The effect of phenobarbital on hyperbilirubinemia in glucuronyl transferase deficient rats. J. Lab. Clin. Med., 70: $273(1967)$

6. Gartner, L. M., and Arias, I. M.: Hormonal control of hepatic bilirubin transport and conjugation. Amer. J. Physiol., 222: 1091 (1972)

7. Gusdon, J. P., Moore, V. L., Myrvik, Q. N., and Holyfield, P. A.: Promethazine$\mathrm{HCl}$ as an immunosuppressant. Amer. J. Obstet. Gynecol., 108: 1340 (1972).

8. Gusdon, J.P., and Witherow, C.: Possible ameliorating effects of erythroblastosis by promethazine hydrochloride. Amer. J. Obstet. Gynecol., 1/7: 101 (1973).

9. Levi, A. J., Gatmaitan, Z., and Arias, I. M.: Deficiency of hepatic anion binding and jaundice in newborn monkeys. N. Eng. J. Med., 283: 1136 (1970).

10. Lowry, O. H., Rosebrough, N. J., Farr, A. L., and Randall, R. J.: Protein measurement with the Folin phenol reagent. J. Biol. Chem. 193: 265 (1951).

11. McMullin, G. P., Hayes, M. F., and Arora, S. C.: Phenobarbitone in rhesus haemolytic disease. Lancet, ii: 949 (1970).

12. Redinger, R. N., and Small, D. M.: Primate biliary physiology. VIII. The effect of phenobarbital upon bile salt synthesis and pool size, biliary secretion and bile composition. J. Clin. Invest., 52: 161 (1973).

13. Reyes, H. Levi, A. J., Gatmaitan, Z., and Arias, I. M.: Organic anion-binding protein in rat liver: Drug induction and its physiologic consequence. Proc. Nat. Acad. Sci. U. S. A., 64: 168 (1969)

14. Reyes, H., Levi, A. J., Gatmaitan, Z., and Arias, I. M.: Studies of Y and Z, two hepatic cytoplasmic organic anion-binding proteins: Effect of drugs, chemicals, hormones and cholestasis. J. Clin. Invest., 50: 2242 (1971).

15. Roberts, R. J., and Plaa, G. L.: Effect of phenobarbital and the excretion of an exogenous bilirubin load. Biochem. Pharmacol., 16: 827 (1967),

16. Rubinestein, A. Eidelman, A. I. Melamed, J. Gartner, L. M., and Kandall, S: Possible effect of maternal promethazine therapy on neonatal immunologic functions. J. Pediat., 89: 136 (1976).

17. Rubinstein, A., Schulman, H., and Eidelman, A. I.: Promethazine immunosuppression of Rh erythroblastosis. Pediat. Res., 9: 326 (1975).

18. Runyòn, R. P., and Haber, A.: Fundamentals of Behavioral Statistics (AddisonWesley Publishing Co., Reading, Mass., 1967).

19. This work was supported by grants from the National Institute for Child Health and Human Development (5R0I-HD03783), NIH International Fellowship Award (3F05 TW01850-0140151), the Gail Zuckerman Foundation for Research in Chronic Liver Diseases of Children, and Liver Research Center of the Albert Einstein College of Medicine.

20. Dr. S. L. Vaisman was a recipient of National Institutes of Health International Fellowship.

21. Dr. L. M. Gartner is Research Career Development Awardee, National Institute for Child Health and Development.

22. Requests for reprints should be addressed to: L. M. Gartner, M. D., Department of Pediatrics, Albert Einstein College of Medicine, 1300 Morris Park Ave., Bronx, N. Y. 10461 (USA).

23. Accepted for publication April 1, 1976
ABO incompatibility, Rhesus incomparibility antibody-dependent cytotoxicity, cell-mediated erythrocytes fetus hemolysis leukocytes

\title{
Antibody-dependent Cell-mediated Destruction of Human Erythrocytes Sensitized in ABO and Rhesus Fetal-Maternal Incompatibilities
}

\author{
S. A. ZAWODNIK, ${ }^{(27)}$ G. D. BONNARD, AND E. GAUTIER \\ Immunogentic Laboratory, Department of Pediatrics, Hôpital Cantonal Universitaire, Lausanne, Switzerland \\ H. R. MACDONALD \\ Department of Immunology, Swiss Institute for Experimental Cancer Research, Lausanne, Switzerland
}

Extract

Antibody-dependent cell-mediated cytotoxicity (ADCMC) was measured in a ${ }^{51} \mathrm{Cr}$-release assay with antibody-sensitized human red blood cells ( $R B C$ ) as target cells and nonimmune isologous or autologous mononuclear peripheral blood leukocytes (MPBL) as effector cells. ADCMC was readily demonstrable within $6 \mathrm{hr}$ and was independent of exogenous complement $\left(C^{\prime}\right)$. The specificity of the $A D C M C$ reaction was determined by the antiserum employed. Anti-A, anti-B, anti-D, and anti-c sera were all active in ADCMC; the specific lysis was between 35 and $50 \%$ with antiserum dilution of $1 / 1,000$, using $10^{5}$ target cells and $10^{6} \mathrm{MPBL}$. Anti-C, anti-E, and anti-e sera had no detectable activity. Sephadex column separation suggested that this activity was by antibodies of the IgG class.
Cord $\mathrm{RBC}$ from infants with $\mathrm{RhD}$ fetal-maternal incompatibility were lysed by autologous or isologous MPBL in the absence of exogenous antiserum. ADCMC was between $22 \%$ and $42 \%$ in.cases with high direct Coombs' test, but was negative with low direct Coombs' test as in five cases of $\mathrm{ABO}$ incompatibility.

\section{Speculation}

In hemolytic disease of the newborn, the precise mechanisms involved in the destruction of fetal erythrocytes sensitized with maternal antibodies are not well known. The experiments described in this report raise the possibility that $\mathrm{ADCMC}$ could be operative in vivo 